\title{
- ГЛОБАЛІЗАЦІЯ ЯК ФЕНОМЕН ТРАНСФОРМАЦІЇ ПОСТКОМУНІСТИЧНОЇ КУЛЬТУРИ: ІСТОРІОГРАФІЯ ПРОБЛЕМИ
}

\section{- Танська Людмила Вацлавівна}

- Старший викладач,

ORCID: 0000-0001-7607-4688, e-mail: tanska2008@ukr.net,

Відкритий міжнародний університет розвитку людини «Україна», вул. Львівська, 23, Київ, Україна, 01115

\section{- Для цитування:}

Танська, Л.В. (2021). Глобалізація як феномен трансформації посткомуністичної культури: історіографія проблеми. Питання культурології, (38), 195-203. doi: https://doi. org/10.31866/2410-1311.38.2021.245894.

\section{- Анотація}

Мета статті - визначити культурно-історичні детермінанти глобалізаційних процесів культури у пострадянському просторі як феномен діалогу культур. Методологію дослідження становлять системний та компаративний методи, що дали змогу визначити специфіку глобалізаційних реалій пострадянського простору. Наукова новизна полягає у розкритті особливостей взаємодії глобалізації культури в цілому та локальних ініціатив національних культур, зокрема української. Висновки. Наголосимо, що глобалізація культури є метафророю, яка не дає можливостей визначити місце окремих культур у просторі тоталізації, гомогенізації та нівеляції культурно-історичного потенціалу в цілому. Посткомуністичний простір, на відміну від пострадянського простору культуротворення, тежє достатньо розмитою дефрініцією, бо ліворадикальний локус не втрачає своєї актуальності. Втім, кореляція глобалістських інтенцій метамодернізму та посткомунізму свідчить про певну стратегію альтерглобалізму поміркованого універсалізму культуротворчих інтенцій. Доведено, що пострадянські країни погано вписуються в ці стратегему та міфологему. Суперетатизм мімікрує в систему національного етатизму за умови розвитку автохтонного капіталізму, який межує з олігархатом. Визначено, що постмодерністське забарвлення національних культур у контексті виникнення стратегії постпостмодерну, або метамодерну, все більше трансформується в різного типу етноренесанси: музеєфікацію, фестивацію традиційних цінностей. Поле діалогу культур звужується, а в умовах локальних конфрліктів між країнами колишнього СРСР взагалі сходить нанівець. Відтак, глобалізація як «модернізація», «макдоналізація», «транзитологія» західних цінностей масової культури є глобалістським синдромом нерівності і відображує вже минулий етап національного будівництва культури. 
Ключові слова: культура; глобалізація; діалог культур; посткомуністичний простір; культурно-історичний потенціал

\section{- Вступ}

Поняття «глобалізація» характеризує екстенсивний вимір культури та свідчить про експансію цифрових технологій у комунікативний простір. Проте культура як цілісність має власні соціоцивілізаційні реалії, її не можна звести до засобів комунікації, трансформації природи тощо. Культурний локус посткомуністичної культури реалізується в сучасних національних культурах, що визначаються «пострадянськими». Цей аспект є пріоритетним для визначення системи тотальності культуротворчості як глобалізаційного феномену.

Проблема культури в контексті глобалізаційних проблем інтерпретується по-різному: як субстанційний вимір антропогенезу (культура є носієм Духу, Великого іншого, Бога), саме такого бачення культури дотримується В. Бичков (Бычков, 2003); культура є засіб переробки природи, в тому числі і природи людини (марксистський підхід) (Каган, 1974; Маркарян, 1982; Межуев, 2011); культура є світ, в якому людині дається образ буття (феноменологічний підхід) (Шелер, 1994; Шинкарук, 2003). В українській фрілософській та культурологічній рефрлексії (розвідки В. Шинкарука (2003), М. Поповича (2005), С. Кримського (Крымский, 2000), В. Іванова (Иванов, 1989) та ін.) також сформувався своєрідний спектр бачення культури як світоглядної цілісності.

Розвідки, присвячені глобалістській проблематиці, є різними. Зокрема, український фрілософр, політик А. Толстоухов (2003) дає ґрунтовний аналіз екологічної проблематики в контексті глобалізації. Дослідження англійських дослідників Д. Гелда, Е. МакГрю, Д. Голдблата, Д. Перратона (2003) свідчать про системний підхід до глобалізаційних процесів, де особлива увага приділялася глобалізації в культурі як культурно-історичному процесу.

Французькі соціологи Д. Мартен, Ж.-Л. Мецжер, Ф. П'єр (2005) критикують глобалізацію, вважають, що це є псевдокатегорія, яка виглядає надзвичайно абстрактним концептом інтерпретації взаємодії країн вищого світу та країн третього світу.

\section{Мета статті}

Мета статті - визначити культурно-історичні детермінанти глобалізаційних процесів культури у пострадянському просторі як соціокультурну цілісність взаємодії культур.

\section{- Виклад матеріалу дослідження}

У традиційному розумінні «Культура - це вся сфрера буття і діяльності людини, що включає її результати, які ініціюються і направляються Духом, i, відповідно, орієнтовані (свідомо або безсвідомо) лише виключно на творче, морально повноцінне, духовно сповнене життя» (Бычков, 2003, с. 556). При цьому сфрера діяльності homo sapiens значно ширша, ніж зазначена у вищенаведеному визначенні, — людина має вільний вибір, постійно удосконалюється у своїй раціональній діяльності, рухає науково-технічний прогрес. У такому разі сфрера 
діяльності людини характеризується вже як цивілізація, головною сутнісною складовою якої залишається культура, оскільки саме вона запліднена Духом і спрямована на розвиток моральних інтенцій людини. Звісно, людина єство дуальне, духовно-тілесне, тому природно, що діяльність задля задоволення матеріальних потреб має місце і також не виключена зі сфери культури. При цьому культура передбачає саме духовні пріоритети, відсутні в цивілізаційних характеристиках.

Така радикалізація відповідає недавнім стратегіям «комуністичного ідеалу», універсалістського розуміння культури як носія абсолютного виміру культуротворення. Втім, комуністичний ідеал у більшості реалізувався як гносеологічний, тобто ідея, позбавлена образної реальності ідентичності акторів соціокультурних відносин. Не менш абстрактною виглядає ідея «Великого Іншого», яка за умови руйнації традиційної релігійної свідомості перетворюється на «національну ідею» або будь-яку іншу абстракцію досягнення абсолюту. Українські дослідники більш детально визначають простір глобалізації як трансактивний феномен. Дослідження В. Кизими (2005), О. Гомілко (2003), Т. Лютого (1995), Є. Андроса (2003), В. Малахова (2001), Р. Шульги (1993) презентують універсалістські аспекти культуротворчості як етико-естетичну цілісність.

На наш погляд, інструментально та технологічно надають модель культури С. Неретина та О. Огурцов, які зазначають певні характеристики семіотичного тлумачення культури. «По-перше, широко використовуються методи структурної лінгвістики і підходи до природних мов як до знакової системи. По-друге, розбудовується семіотика інших знакових систем, у тому числі і френоменів культури як знакових систем. По-третє, культура інтерпретується як складна система семіотичних кодів різних видів, починаючи з мови жестів і закінчуючи такими об'єктами, як одяг, ритуал, міф та ін. По-четверте, культура розуміється як текст, а сам текст як сигнал або повідомлення, що просторово зафріксоване та закодоване і слугує засобом передання цього повідомлення. По-п'яте, фріксується складна взаємодія між різними кодами і знаковими системами. По-шосте, ця взаємодія характеризує поліфункціональну природу людської активності» (Hеретина \& Огурцов, 2000, с. 268).

Отже, ми маємо по суті кілька моделей глобалізації культури - лінгвістичну, семіотичну, комунікативну. Антиглобалістські тенденції в українській культурі були зазначені вже у так звані нульові роки XXI століття. О. Зінькевич (2008), розмірковуючи над можливими наслідками євроінтеграції для культури України та Європи, застерігає про небезпеку втрати етнічної ідентичності національної культури в денаціоналізованому європейському контексті. Європейська ж культура, на його думку, збагатиться свіжими силами, можливо, спостерігатиметься інтерес до української культури як до нового екзотичного явища.

Культура або приймає модель тигля, в якому переплавляються всі етнострої буття людини (американський варіант), або стає низкою альтерглобалізаційних інтенцій, що походять від національних культур. А. Толстоухов (2003) характеризує глобальний соціальний контекст як «багатовимірний антропогенний універсум, що виник і функціонує як інтегральний продукт складних інтеракцій» на всіх рівнях: міжнаціональному, мультинаціональному, надетнічному. У сучасній 
методології гуманітарних досліджень «цей універсум осмислюється як активне нелінійне середовище, в якому (подібно до картезіанських вихорів) виникають взаємодії та історично еволюціонують різноманітні соціальні сорери - бізнесу, інформації, знання, науки, індустрії, наукомістких технологій тощо» (с. 9).

Такий «індустріалістський» підхід корелює з культуроморфною моделлю глобалізації. Так, Д. Гелд, Е. МакГрю, Д. Голдблат, Д. Перратон (2003) відмічають, що у власних дискусіях викрилося три типи обґрунтувань щодо характеру глобалізації. Гіперглобалісти прогнозують гомогенізацію світу внаслідок тиску американської поп-культури та західного консюмеризму. Скептики на противагу глобалістам висувають застереження про поверховість та штучність глобальних типів культур, відстоюючи глибину культур національних та відзначаючи важливість культурних відмінностей на тлі геополітичних прорахунків головних світових цивілізацій. Прихильники трансформаціоністської політики характеризують культурні наслідки глобалізації як народження нових культурних гібридів та появу нових культурних глобальних мереж.

Глобалізація як культурний феномен розпочалася не в XIX або XX столітті, а з виникненням великих імперій, зокрема, елінізації світу, розповсюдженням світових релігій, модерними трансформаціями економіки. В будь-який історичний період зусилля державних установ, різних соціальних сил, інституцій спрямовувалися на формування національних ідентичностей, національних культур. Результатом «нерідко було створення нових культурних інфраструктур на певних територіях із державними кордонами і забезпечення каналів поширення новосформованих уявлень про національні культури та ідентичності, а там, де було треба, - для регулювання, придушення чи використання ідентичності та місцевих проявів націоналізму» (Гелд та ін., 2003, с. 397).

Французькі соціологи розглядають феномен глобалізації як легалізацію «нерівності», прикриту ширмою егалітаризму, посилаючись на те, що не існує ані світового уряду, ані світової армії (про що свідчить неспроможність Організації Об'єднаних Націй у забезпеченні миру під час міжетнічних чи міждержавних конфрліктів), ані світового права (дуже складно притягти до судової відповідальності колишніх чи нинішніх диктаторів), ані світової поліції, ані світового збирача податків (Мартен та ін., 2005).

Не менш гостро піддають критиці сучасні українські політологи «універсалізм» соціалістичної культури та соцреалізму. Зокрема, М. Рябчук (2010) вважає, що в СРСР існував не соціалізм, а різновид державного капіталізму. В ідеологічному плані система була комуністичною (нав'язувала обов'язкову для всіх комуністичну ідеологію), в політичному — тоталітарною, бо виражала диктатуру однієї партії. Система ж реального соціалізму розбудовується соціал-демократами без претензій на втілення комуністичних утопічних ідей. Важливо не затирати в радянському комунізмі його найважливішу рису - тоталітарний характер. Відповідно, треба говорити не про соціалістичний табір, не про «країни народної демократії», в яких не було жодної демократії та соціалізму, а про комуністичні країни з комуністичною диктатурою.

Отже, будівництво культури підмінюється будівництвом держави - етатизмом. У системі соціалізму, однак, виникає нова форма етатизму - суперета- 
тизм. На думку О. Тарасова (1996), при суперетатизмі власником є держава, відповідно громадяни - наймані працівники у неї на службі. Експлуатуючи працівників, держава привласнює продукти їх діяльності. Суспільство поділяється на три класи: робітники, селяни, працівники розумової сфрери (чиновництво та інтелігенція). Певною мірою складається однорідність, одновимірність суспільства: полегшується перехід з одного класу до іншого, оскільки межі між класами розмиваються, і це в порівнянні з капіталістичним суспільством $є$ перевагою. Комунізм був здійснений у вигляді так званого «реального соціалізму», казарменої системи розподілу благ, коли робітникам не доплачували зарплату, а недоплата «поверталася» у вигляді безкоштовних послуг, компенсуючи ії системою охорони здоров'я та комунальними благами.

Загальне тло глобалізаційної стратегії поступово перетворюється на постмодерністську гру із загрозами та ризиками, своєрідний енвайронмент. Д. Гелд, Е. МакГрю Д. Голдблат, Дж. Перратон (2003) пишуть: «В останні три десятиліття 20 ст. синонімом глобального світогляду стає енвайронменталізм. Науковці в царині біології, екології та інших наук попереджають про небезпеку змін у довкіллі, які мають глобальні причини та наслідки. 3 огляду на це «стрімко зростає число та масштаб дії міжнародних інститутів, правових актів та угод, покликаних регулювати питання природного середовища поряд зі створенням низки міжнародних альянсів, екологічних рухів та організацій» (c. 437).

\section{- Висновки}

Пострадянські країни погано вписуються у створені стратегему та міфрологему. Суперетатизм мімікрує в систему національного етатизму за умови розвитку автохтонного капіталізму, який межує з олігархатом. Легалізувати систему нерівності в рамках євроменталізму неможливо, бо ще існує пам'ять про «розвинений соціалізм», безкоштовну медицину та ін. Досвід китайського адаптивного капіталізму в упаковці комуністичної ідеології є унікальним та локальним, який не піддається «транзиту».

Постмодерністське забарвлення національних культур у контексті виникнення стратегії постпостмодерну, або метамодерну, все більше трансформується в різного типу етноренесанси: музеєфікацію, фестивацію традиційних цінностей. Поле діалогу культур звужується, а в умовах локальних війн між країнами колишнього СРСР взагалі сходить нанівець. Проте екологічне підґрунтя $є$ спільним для всіх і спонукає до діалогу. Відтак, глобалізація як «модернізація», «макдоналізація», «транзитологія» західних цінностей масової культури є глобалістським синдромом нерівності і відображує минулий етап національного будівництва культури.

\section{- Список використаних джерел}

Андрос, Є.І. (2003). Всезагальне та індивідуальне в культурі за умов глобалізації. В Людина і культура в умовах глобалізації (с. 85-93). Парапан.

Бычков, В. В. (Ред.). (2003). Лексикон нонклассики. Художественно-эстетическая культура XX века. Российская политическая энциклопедия (РОССПЭН). 
Гелд, Д., МакГрю, Е., Голдблат, Д., \& Перратон, Д. (2003). Глобальні трансформації (В. Курганський, В. Сікора, Пер.) Фенікс.

Гомілко, О. Є. (2003). Глобальні трансформації людської тілесності. В Людина і культура в умовах глобалізації (с. 129-136). Парапан.

Зінькевич, О.С. (2008). Дискусійні питання мультикультурних процесів. Часопис Національної музичної академії України імені П. І. Чайковського, 1(1), 82-89.

Иванов, В. П. (1989). Культура и человеческая деятельность. В Культура и развитие человека: очерк фрилософрско-методологических проблем (с. 13-67). Наукова думка.

Каган, М. С. (1974). Человеческая деятельность. Опыт системного анализа. Политиздат.

Кизима, В. В. (2005). Тоталлогия. Парапан.

Крымский, С. Б. (2000). Философиия как путь человечности и надежды. Курс.

Лютий, Т. В. (1995). Кратологія та глобалізація. В Політологія посткомунізму (с. 115-121). Політична думка.

Малахов, В. А. (2001). Етика. Либідь.

Маркарян, Э. С. (1982). Теория культуры и современная наука. Мысль.

Мартен, Д., Мецжер, Ж.-Л., \& П'ер, Ф. (2005). Метаморфози світу. Социология глобализации ( $€$. Маричев, Пер.). КМ Академія.

Межуев, В. М. (2011). История, цивилизация, культура: опыт фрилософрского истолкования. Издательство Санкт-Петербургского Гуманитарного университета профсоюзов.

Неретина, С., \& Огурцов, А. (2000). Время культуры. Издательство Русского Христианского гуманитарного института.

Попович, М. В. (2005). Червоне століття. АртЕк.

Рябчук, Н. (2010, 1 июня). Украинская посткоммунистическая трансфрормация: между дисфункциональной демократией и неконсолидованным авторитаризмом. https://polit.ru/article/2010/06/01/ukraine/

Тарасов, А. (1996, 5 мая-7 июня). Суперэтатизм и социализм. Скепсис. https//:scepsis. net//libraru/id_102.html

Толстоухов, А. В. (2003). Глобалізація. Влада. Еко-майбутнє. Парапан.

Шелер, М. (1994). Избранные произведения. Гнозис.

Шинкарук, В. І. (2003). Вибрані твори (Т. 2). Український Центр духовної культури.

Шульга, Р. П. (1993). Искусство в мире обыденного сознания. Наукова думка.

\section{- References}

Andros, Ye. I. (2003). Vsezahalne ta indyvidualne v kulturi za umov hlobalizatsii [Universal and individual in culture in the context of globalization]. In Liudyna i kultura $v$ umovakh hlobalizatsii [Man and Culture in the Context of Globalisation] (pp. 85-93). Parapan [in Ukrainian].

Bychkov, V. V. (Ed.). (2003). Leksikon nonklassiki. Khudozhestvenno-esteticheskaya kul'tura $X X$ veka [Lexicon of Nonclassics. Artistic and Aesthetic Culture of the Twentieth Century]. Rossiiskaya politicheskaya entsiklopediya (ROSSPEN) [in Russian].

Geld, D., McGrew, E., Goldblat,t D., \& Perraton, D. (2003). Hlobalni transformatsii [Global Transformations] (V. Kurhanskyi, V. Sikora, Trans.) Feniks [in Ukrainian]. 
Homilko, O. Ye. (2003). Hlobalni transformatsii liudskoi tilesnosti [Global transformations of the human body]. In Liudyna i kultura $v$ umovakh hlobalizatsii [Man and Culture in the Context of Globalization] (pp. 129-136). Parapan [in Ukrainian].

Ivanov, V. P. (1989). Kul'tura i chelovecheskaya deyatel'nost' [Culture and human activity]. In Kul'tura i razvitie cheloveka: ocherk filosofsko-metodologicheskikh problem [Culture and Human Development: an Outline of Philosophical and Methodological Problems] (pp. 13-67). Naukova dumka [in Russian].

Kagan, M. S. (1974). Chelovecheskaya deyatel'nost'. Opyt sistemnogo analiza [Human Activity. Experience of System Analysis]. Politizdat [in Russian].

Kizima, V. V. (2005). Totallogiya [Totallogy]. Parapan [in Russian].

Krymskii, S. B. (2000). Filosofiya kak put' chelovechnosti i nadezhdy [Philosophy as a Way of Humanity and Hope]. Kurs [in Russian].

Liutyi, T. V. (1995). Kratolohiia ta hlobalizatsiia [Kratology and globalisation]. In Politolohiia postkomunizmu [Political Science of Post-communism] (pp. 115-121). Politychna dumka [in Ukrainian].

Malakhov, V. A. (2001). Etyka [Ethics]. Lybid [in Ukrainian].

Markaryan, E. S. (1982). Teoriya kul'tury $i$ sovremennaya nauka [Theory of Culture and Modern Science]. Mysl' [in Russian].

Martin, D., Metzger, J.-L., \& Pierre, F. (2005). Metamorfozy svitu. Sotsyolohyia hlobalyzatsyy [Metamorphoses of the World. Sociology of Globalisation] (le. Marychev, Trans.). KM Akademiia [in Ukrainian].

Mezhuev, V. M. (2011). Istoriya, tsivilizatsiya, kul'tura: opyt filosofskogo istolkovaniya [History, Civilisation, Culture: Experience of Philosophical Interpretation]. Izdatel'stvo SanktPeterburgskogo Gumanitarnogo universiteta profsoyuzov [in Russian].

Neretina, S., \& Ogurtsov, A. (2000). Vremya kul'tury [Time of Culture]. Izdatel'stvo Russkogo Khristianskogo gumanitarnogo institute [in Russian].

Popovych, M. V. (2005). Chervone stolittia [The Red Age]. ArtEk [in Ukrainian].

Riabchuk, N. (2010, Juni 1). Ukrainskaya postkommunisticheskaya transformatsiya: mezhdu disfunktsional'noi demokratiei i nekonsolidovannym avtoritarizmom [Ukrainian Postcommunist Transformation: Between Dysfunctional Democracy and Unconsolidated Authoritarianism]. https://polit.ru/article/2010/06/01/ukraine/ [in Russian].

Sheler, M. (1994). Izbrannye proizvedeniya [Selected Works]. Gnozis [in Russian].

Shulha, R. P. (1993). Iskusstvo v mire obydennogo soznaniya [Art in the World of Ordinary Consciousness]. Naukova dumka [in Russian].

Shynkaruk, V. I. (2003). Vybrani tvory [Selected Works] (Vol. 2). Ukrainskyi Tsentr dukhovnoi kultury [in Ukrainian].

Tarasov, A. (1996, May 5 - Juni 7). Superetatizm i sotsializm [Superetatism and Socialism]. Skepsis. https//:scepsis.net//libraru/id_102.html [in Russian].

Tolstoukhov, A. V. (2003). Hlobalizatsiia. Vlada. Eko-maibutnie [Globalisation. Power. Ecofuture]. Parapan [in Ukrainian].

Zinkevych, O. S. (2008). Dyskusiini pytannia multykulturnykh protsesiv [Discussion issues of multicultural processes]. Chasopys Natsionalnoi Muzychnoi Akademii Ukrainy imeni P. I. Chaikovskoho, 1(1), 82-89 [in Ukrainian]. 


\section{GLOBALISATION AS A PHENOMENON OF THE TRANSFORMATION OF POST-COMMUNIST CULTURE: THE HISTORIOGRAPHY OF THE ISSUE}

\section{- Liudmyla Tanska}

- Senior Lecturer, ORCID: 0000-0001-7607-4688, e-mail: tanska2008@ukr.net, Open International University of Human Development "Ukraine", Kyiv, Ukraine

\section{- Abstract}

The purpose of the article is to determine the cultural and historical determinants of globalisation processes of culture in the post-Soviet space as a phenomenon of dialogue of cultures. The research methodology consists of systematic and comparative methods that made it possible to determine the special features of the globalisation realities of the postSoviet space. The scientific novelty consists in revealing the features of interaction between the globalisation of culture in general and local initiatives of national cultures, in particular Ukrainian. Conclusions. It should be noted that the globalisation of culture is a metaphor that does not allow us to determine the place of individual cultures in the space of totalisation, homogenisation and levelling of cultural and historical potential as a whole. The post-communist space, in contrast to the post-Soviet space of cultural creation, is also a rather vague definition, because the leftwing radical locus does not lose its relevance. However, the correlation of globalist intentions of metamodernism and post-communism indicates a certain strategy of alterglobalism a moderate universalism of cultural intentions. The article demonstrates that post-Soviet countries do not fit well into this strategy and mythologeme. Superetatism mimics the system of national ethatism under the condition of the development of autochthonous capitalism, which borders on the oligarchy. It is determined that the postmodern colouring of national cultures in the context of the emergence of postmodern or metamodern strategy is increasingly transformed into different types of ethnic renaissance: museification, festival of traditional values. The field of dialogue of cultures is narrowing, and in the conditions of local conflicts between the countries of the former USSR, it disappears at all. Thus, globalisation as "modernisation", "McDonaldization", "transitology" of Western values of mass culture is a globalist syndrome of inequality and reflects the past stage of national culture.

Keywords: culture; globalisation; dialogue of cultures; post-communist space; cultural and historical potential 


\section{- ГЛОБАЛИЗАЦИЯ КАК ФЕНОМЕН ТРАНСФОРМАЦИИ ПОСТКОММУНИСТИЧЕСКОЙ КУЛЬТУРЫ: ИСТОРИОГРАФИЯ ПРОБЛЕМЫ}

\section{- Танская Людмила Вацлавовна}

Старший преподаватель, ORCID: 0000-0001-7607-4688, e-mail: tanska2008@ukr.net, Открытый международный университет развития человека «Украина», Киев, Украина

\section{- Аннотация}

Цель статьи - определить культурно-исторические детерминанты глобализационных процессов культуры в постсоветском пространстве как феномен диалога культур. Методологию исследования составляют системный и компаративный методы, которые позволили определить специфику глобализационных реалий постсоветского пространства. Научная новизна заключается в раскрытии особенностей взаимодействия глобализации культуры в целом и локальных инициатив национальных культур, в частности украинской. Выводы. Отметим, что глобализация культуры является метафорой, которая не дает возможность определить отдельные культуры в пространстве тотализации, гомогенизации и нивелирования культурно-исторического потенциала в целом. Посткоммунистическое пространство, в отличие от постсоветского пространства культуротворчества, тоже является достаточно размытой дефиницией, потому леворадикальный локус не теряет своей актуальности. Впрочем, корреляция глобалистских интенций метамодернизма и посткоммунизма свидетельствует об определенной стратегии альтерглобализма умеренного универсализма культуротворческих интенций. Доказано, что постсоветские страны плохо вписываются в эти стратегему и мифологему. Суперэтатизм мимикрирует в систему национального этатизма при условии развития автохтонного капитализма, который граничит с олигархатом. Определено, что постмодернистская окраска национальных культур в контексте возникновения стратегии постпостмодерна, или метамодерна, все больше трансформируется в разного типа этноренессансы: музеефикацию, фестивацию традиционных ценностей. Поле диалога культур сужается, а в условиях локальных конфрликтов между странами бывшего СССР вообще сходит на нет. Следовательно, глобализация как «модернизация», «макдонализация», «транзитология» западных ценностей массовой культуры является глобалистским синдромом неровности и отображает уже прошедший этап национального строительства культуры.

Ключевые слова: культура; глобализация; диалог культур; посткоммунистическое пространство; культурно-исторический потенциал 